\title{
APLIKASI TEMA DESAIN RUMAH SAKIT IBU DAN ANAK BERDASARKAN KARAKTER PENGGUNA RUANG
}

\author{
Latifah Utary, Setiamurti Raharadjo, Doddy Friestya Asharsinyo \\ Universitas Telkom, Universitas Telkom \\ latifahutry@telkomuniversity.ac.id
}

\begin{abstract}
Abstrak.Selain sebagai suatu sarana kesehatan khusus yang melayani pemeriksaan ibu selama masa pra hingga pasca melahirkan dan memberikan pelayanan bagi kesehatan anak-anak, Rumah Sakit Ibu dan Anak juga harus memperhatikan aspek kejiwaan atau psikologi pasien dan kebutuhan pasien dalam tatanan desain untuk dapat mendukung proses pemulihan. Selain dibutuhkannya fasilitas yang dapat mewadahi seluruh aktivitas pengguna, juga dibutuhkan nya suasana ruang yang dapat memberikan rasa nyaman ketika berada didalamnya. Salah satu cara untuk membangun suasana ruang yang diinginkan pengguna yaitu dengan penerapan tema pada ruang. Oleh karena itu, penulisan ini bertujuan untuk menentukan tema yang sesuai dengan karakter pengguna dan bagaimana proses dalam penentuan tema tersebut. Penelitian dilakukan dengan menggunakan metode kuantitatif melalui kuesioner lalu dilanjutkan dengan metode kualitatif yang akan membahas proses penentuan tema dan tema yang diingikan masyarakat saat ini untuk Rumah Sakit Ibu dan Anak.
\end{abstract}

Kata kunci : Rumah Sakit Ibu dan Anak, Suasana, Tema

Abstract. Other than as a means of serving the special health examination of the mother during the pregnancy to pre post childbirth and providing service for the health of children, mothers and children's hospital must also pay attention to aspects of psychiatric or psychological patients and patient needs in order to design can support the recovery process. In addition to the need for facilities that can accomodate an entire user activity, its atmosphere also required space can provide a sense of comfort when residing therein. One way to build the desired room atmosphere users by application of the theme on the space. Therefore, the writing aims to determine the themes that correspond to the user's character and how these themes in the determination process. Research carried out using quantitative methods through questionnaires and continued with the qualitative method which will discuss the process of determining the desired theme and the theme of today's society for interior Women's and Children's Hospital.

Keywords: Women's and Children's Hospital, Atmosphere, Theme

\section{PENDAHULUAN}

\section{Latar Belakang}

Selain sebagai suatu sarana kesehatan khusus yang melayanai pemeriksaan ibu selama masa pra kehamilan hingga pasca melahirkan dan memberikan pelayanan kesehatan bagi anak-anak, Rumah Sakit Ibu dan Anak juga harus memperhatikan aspek-aspek yang berhubungan dengan pengguna ruang dengan memperhatikan tatanan desain lingkungan fisik untuk mendukung proses pemulihan. Rancangan lingkungan fisik dapat mempengaruhi pilihan, harapan, kepuasan, serta perilaku konsumen, tidak terkecuali pada rancangan rumah sakit sebagai tempat berinteraksi antara konsumen dan penyedia jasa pelayanan kesehatan (Prasetyo, 2016). Kondisi lingkungan yang baik tidak hanya memberi nilai positif pada pasien (Lawson dan Phiri, 2000), tetapi juga berperan dalam membantu kesembuhan (Annemans, et. al, 2017). Sama seperti lingkungan fisik pada umumnya, kualitas fisik rumah sakit yang baik ditentukan oleh berbagai aspek, seperti halnya ketersediaan dan kenyamanan fasilitas, kondisi 
pencahayaan, penghawaan, maupun pemilihan material yang tidak berbahaya bagi kesehatan. Berbagai macam aspek teknis sudah banyak disinggung dalam panduan perancangan rumah sakit maupun ketetapan standar yang dikeluarkan oleh pemerintah, sedangkan dalam lingkup dekorasi, beberapa studi telah dilakukan mengenai karya-karya seni yang berperan dalam kesembuhan (Whaley, 2018). Dalam interior fasilitas kesehatan, seni adalah alat untuk menginspirasi dan alat bantu penyembuhan, melalui seni yang familiar dan menginspirasi dapat membantu memberikan energi yang positif juga menjadi alat transisi pada area-area publik dimana pengunjung dapat berinteraksi dengan seni dalam level yang berbeda (Mc Cullough, 2009). Gesler (2014) dalam penelitiaanya menyimpulkan bahwa 75\% Pengunjung dan pasien mengatakan sebuah seni dapat mengurangi tingkat stress mereka dan dapat mengalihkan pikiran mereka dari masalah dan kekhawatiran. Namun demikian, referensi mengenai ketentuan estetika dalam desain interior masih jarang ditemukan, sehingga penelitian ini diharapkan dapat berkontribusi memberi pandangan desain rumah sakit melalui aspek estetika.

Secara umum, estetika ruang interior dapat dicapai melalui penerapan tema maupun gaya. Jika gaya (style) sudah memiliki kebakuan istilah berdasarkan periode kemunculannya, maka tema memiliki sifat yang lebih fleksibel dan dapat dicapai melalui berbagai cara kreatif seorang desainer. Aplikasi tema dalam desain interior tidak hanya sebagai cara untuk mengekspresikan fungsi ruang dan suasana yang akan dihadirkan, tetapi juga sebagai upaya untuk mengintegrasikan elemen-elemen ruang menjadi sebuah kesatuan desain. Selain itu, tema seringkali dipakai untuk memunculkan keunikan estetika desain secara lebih bertanggung jawab. Pada penelitian terdahulu, telah ditemukan bahwa fungsi yang didedikasikan untuk anak-anak efektif mencapai daya tariknya melalui desain tematik karena mudah dicerna melalui persepsi secara visual (Rahardjo dan Handoyo, 2015), sementara ruang untuk wanita pada umumnya ditampilkan dalam desain bernuansa feminin. Berangkat dari latar belakang tersebut, penelitian ini akan mengulas mengenai tema yang dapat diterima oleh para pengguna Rumah Sakit Ibu dan Anak, dengan cara mengkaji karakter pengguna terutama pasien wanita hamil dan anak-anak. Dengan begitu dapat ditemukan usulan tema yang dapat menciptakan ruang interior yang bernilai positif bagi pasien.

\section{Kajian Teori}

Tema merupakan gagasan atau ide dasar yang dijadikan sebagai acuan dalam merancang (Indrawiras, 2015). Tema-tema dalam interior didukung oleh berbagai faktor, selain penataan interior yang sesuai dengan tuntutuan fungsi serta aktivitas, penggunaan material dan elemenelemen interior yang tepat akan membentuk dan memperkuat penerapan tema pada interior (Kusnaedi, 2013). Tema ruang yang akan diwujudkan menjadi suatu desain yang berdasar pada karakter pengguna dapat dikaji ke setiap unsur desain sehingga dapat ditangkap dengan baik oleh indera pengunjung melalui analisis persepsi mereka dan akan menciptakan komunikasi yang baik antara ruang dan pengunjung di dalamnya (Sjach, 2012). Pencapaian tema pada ruang akan menciptakan suasana suatu ruang yang memiliki efek pada penggunanya melalui peningkatan desain yang estetik dalam upaya untuk mengurangi tingkat stress dan kecemasan, meningkatkan kepuasan pasien, dan meningkatkan kesehatan dan penyembuhan (Schwitzer, et. al., 2004).

Departemen Kesehatan RI dalam Klasifikasi dan Regionalisasi Rumah Sakit menjelaskan bahwa Rumah Sakit Ibu dan Anak merupakan rumah sakit yang khusus melayani pemeriksaan ibu hamil dari pra kehamilan hingga pasca melahirkan dan kesehatan anak yang dalam klarifikasinya menyatakan bahwa sebuah rumah sakit ibu dan anak perlu dibuat berdasarkan 
karakteristik penggunanya. Dalam pengembangan desain interior Rumah Sakit Ibu dan Anak, desain yang diciptakan perlu disesuaikan berdasar kepada karakter penggunanya melalui penerapan tema pada ruang. Di Rumah Sakit Ibu dan Anak terdapat dua kelompok pengguna yaitu ibu dan anak, dimana karakter ibu yang dapat diwujudkan dalam ruang tidak hanya menghadirkan nuansa ruang yang feminim, karena wanita juga memiliki preferensi yang netral sehingga juga bisa menghadirkan suasana ruang yang maskulin melalui pemilihan warna (Bogicevic, et. al., 2018). Tetapi nuansa feminim tidak dapat dihilangkan sepenuhnya karena dibutuhkannya pembeda antara Rumah Sakit ibu dan Anak dengan Rumah Sakit lainnya. Sedangkan untuk anak-anak, Rahardjo dan Handoyo (2015) menyimpulkan bahwa tema yang ikonik lebih menarik untuk anak-anak. Anak-anak lebih menghargai lingkungan interior yang mencerminkan kebutuhan dan minat yang berkembang sesuai dengan kebutuhan fasilitas/aktivitas bermain yang sesuai usia di area tunggu, interior yang kreatif dan nyaman dalam penerapan warna, bentuk, pola, dan teksture, sehingga menciptakan lingkungan yang fleksibel dan kontemporer (Lambert, et. al., 2013). Selain itu, menanggapi studi Ozkan, et. al. (2017) menyebutkan bahwa konsumen masa kini lebih menyukai gaya di era kontemporer karena tidak memiliki kompleksitas yang tinggi secara visual, maka dari itu pada penelitian ini ulasan mengenai tema selanjutnya akan dilakukan dalam lingkup desain kontemporer.

\section{METODE PENELITIAN}

Pada penelitian ini metode yang digunakan merupakan penggabungan dari metode kuantitatif dan kualitatif, berikut metode yang dilakukan.

a. Metode kuantitatif dilakukan dengan cara pengumpulan data secara terukur melalui hasil kuesioner terkait suasana ruang yang sesuai untuk interior Rumah Sakit Ibu dan Anak, karakter ibu dan anak-anak, dan suasana ruang yang diinginkan masyarakat saat ini dengan mencantumkan gambar-gambar referensi ruang interior dengan lingkup ruang kontemporer untuk interior Rumah Sakit Ibu dan Anak. Selanjutnya penelitian dan pengumpulan data dilakukan melalui wawancara pada beberapa narasumber yang pernah mengunjungi dan melakukan perawatan di Rumah Sakit Ibu dan Anak, hasil wawancara bertujuan untuk mendapatkan penilaian pengguna terhadap Rumah Sakit Ibu dan Anak saat ini secara subjektif terkait pandangan dan kesan pertama ketika berada di rumah sakit.

b. Metode Kualitatif berupa pengolahan data yang berisi analisa terhadap metodologi desain dalam penentuan tema yang diinginkan masyarakat saat ini.

\section{HASIL PENELITIAN DAN PEMBAHASAN}

Pada penelitian ini, metode dalam penentuan tema pada interior Rumah Sakit Ibu dan Anak akan diterapkan melalui karakter dari pengguna ruang yaitu ibu dan anak-anak. Dengan hasil penelitian dan pembahasan sebagai berikut.

\section{Karakter Ibu dan Anak}

Penelitian dilakukan dengan metode kuantitatif melalui kuesioner yang diisi oleh 135 responses dengan hasil sebagai berikut :

1. Rata-rata responses merupakan perempuan yang berada pada rentang usia 20-30 tahun 


\section{Jenis Kelamin}

135 responses

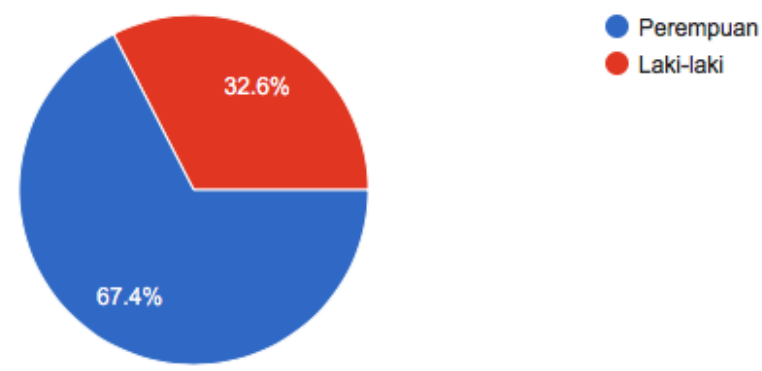

Gambar 1. Diagram Jenis Kelamin Responses Sumber: Google Form

\section{Usia}

135 responses

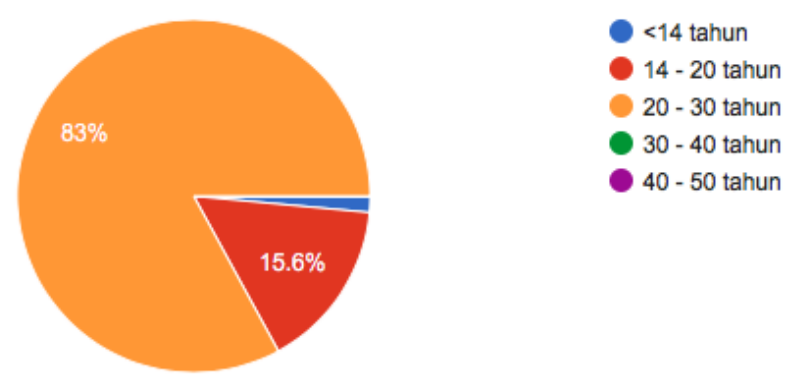

Gambar 2. Diagram Usia Responses

Sumber: Google Form

2. Persentasi responses yang pernah mengunjungi rumah sakit ibu dan anak sebagai acuan dalam penentuan kelayakan data. Dari 135 responses, sebanyak $82.2 \%$ pernah mengunjungi atau menjadi pasien di Rumah Sakit Ibu dan Anak

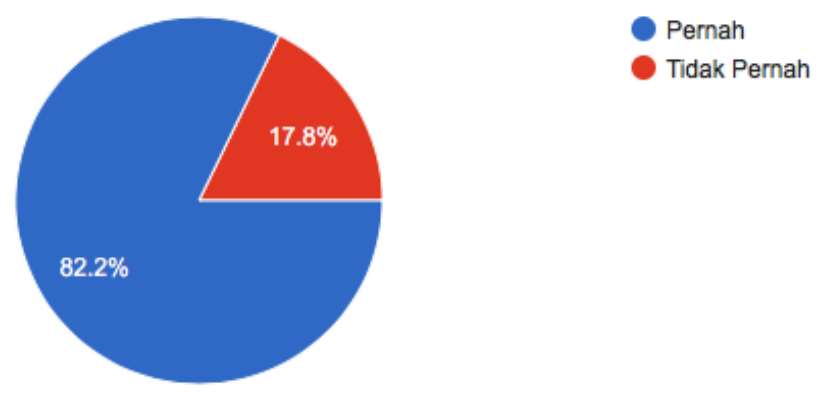

Gambar 3. Diagram Presentasi Responses

Sumber: Google Form

Kuesioner ini bertujuan untuk menemukan satu kata yang menggambarkan karakter ibu dan anak, dari 135 responses diambil data dengan poling terbanyak, yaitu : 
Tabel 1. Karakter Ibu dan Anak

\begin{tabular}{cc}
\hline Ibu & Karakter \\
Anak-anak & Penyayang, Kuat, Lembut, Hangat, Ramah \\
\hline
\end{tabular}

Sumber: Hasil Analisa Pribadi

Dari kata-kata kunci yang ada pada tabel diatas, akan menjadi acuan dalam penentuan tema interior rumah sakit yang akan diterapkan pada elemen pembentuk dan pengisi interior, sehingga dapat menciptakan ruang dengan tema yang sesuai dengan karakter penggunanya.

\section{Suasana Ruang RSIA yang Diinginkan}

Berdasarkan data yang diperoleh dari kuesioner yang membahas mengenai suasana ruang yang diinginkan masyarakat untuk interior Rumah Sakit Ibu dan Anak saat ini dicantumkan pada presentasi berikut ini :

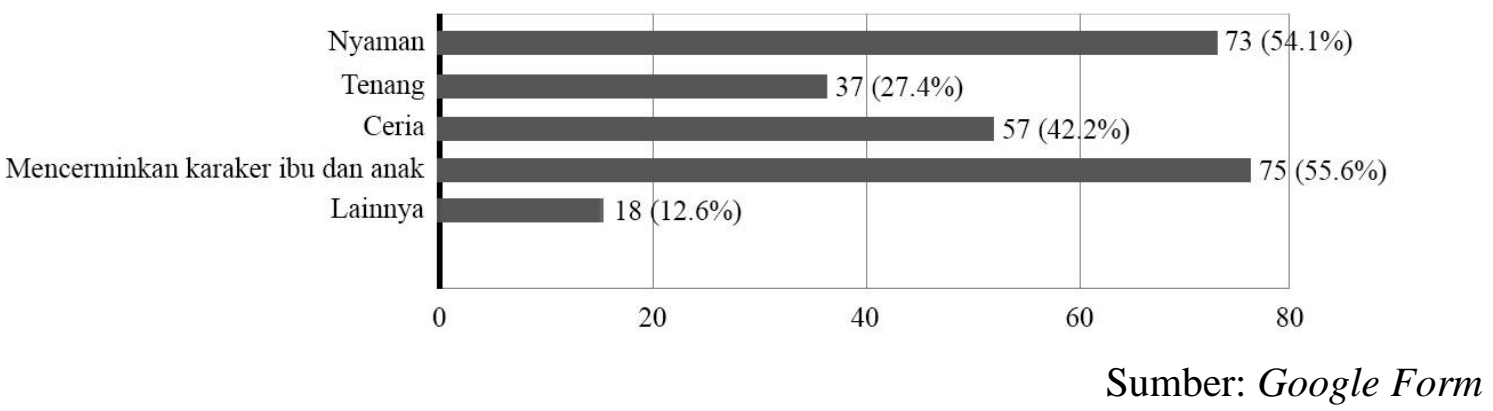

Gambar 3. Diagram Presentasi Suasana Ruang

Dari diagram diatas, diperoleh data tertinggi yaitu sebanyak $54.1 \%$ responses menginginkan suasana ruang yang nyaman, $27.4 \%$ menginginkan suasana ruang yang tenang, $42.2 \%$ responses menginginkan suasana yang ceria, dan $55.6 \%$ responses menginginkan suasana ruang yang mencerminkan karakter pengguna (ibu dan anak). Presentasi terbesar menyebutkan bahwa suasana ruang yang paling diinginkan bagi interior rumah sakit ibu dan anak yaitu suasana ruang yang menggambarkan karakteristik penggunanya (ibu dan anak). Untuk suasana ruang yang diingikan berdasarkan gambar yang dicantumkan pada kuesioner, berikut opsi yang ditampilkan pada kuesioner dan suasana yang ditampilkan melalui gambar.

Alasan pemilihan gambar yang dicantumkan pada kuesioner :

1. Option 1 : Suasana yang dihadirkan pada gambar referensi yaitu clean, luas, seperti rumah sakit pada umumnya dan juga menghadirkan kesan ruang dengan penerapan konsep high-tech

2. Option 2 : Suasana ruang yang dihadirkan terkesan homey, dengan penggunaan material karpet, fasilitas duduk berupa sofa, pemilihan warna, serta kesan ruang yang dihadirkan seperti berada di rumah

3. Option 3 : Suasana ruang yang terkesan tenang dengan penerapan warna dan permainan teknik pencahayaan 
4. Option 4 : Menghadirkan suasana ruang yang natural dengan pemilihan material, warna, dan suasana yang membawa unsur alam kedalam ruangan.

5. Option 5 : Penerapan warna-warna yang ceria dan pemilihan teknik dan pencahayaan menghadirkan suasana ruang yang ceria.

6. Option 6 : Penggunaan warna-warna lembut dan warna pink membuat suasana ruang yang feminim dan penerapan bentuk ruang dan furniture yang dinamis serta pemilihan teknik pencahayaan membuat suasana ruang yang tidak kaku

Option 1

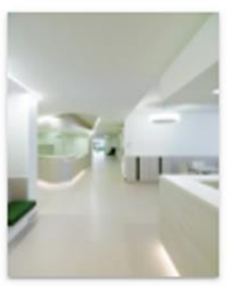

Option 2

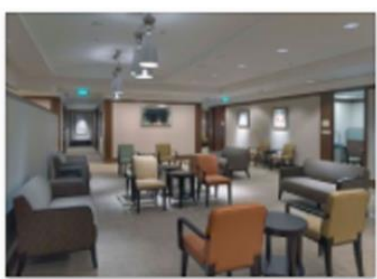

Option 3

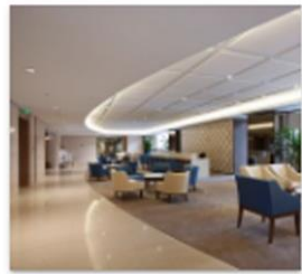

Option 4

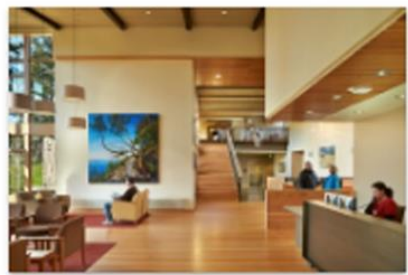

Option 5

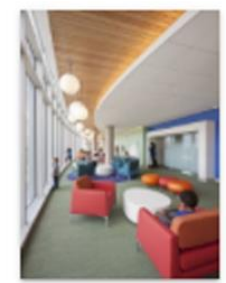

Option 6

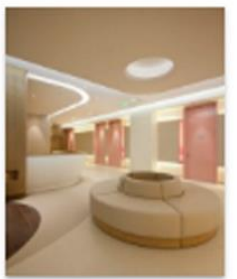

Gambar 4. Pilihan Suasana Ruang yang Diinginkan Responses Sumber: Google Form

Dari ke enam opsi diperoleh presentasi suasana ruang yang diinginkan pada Rumah Sakit Ibu dan Anak sebagai berikut :

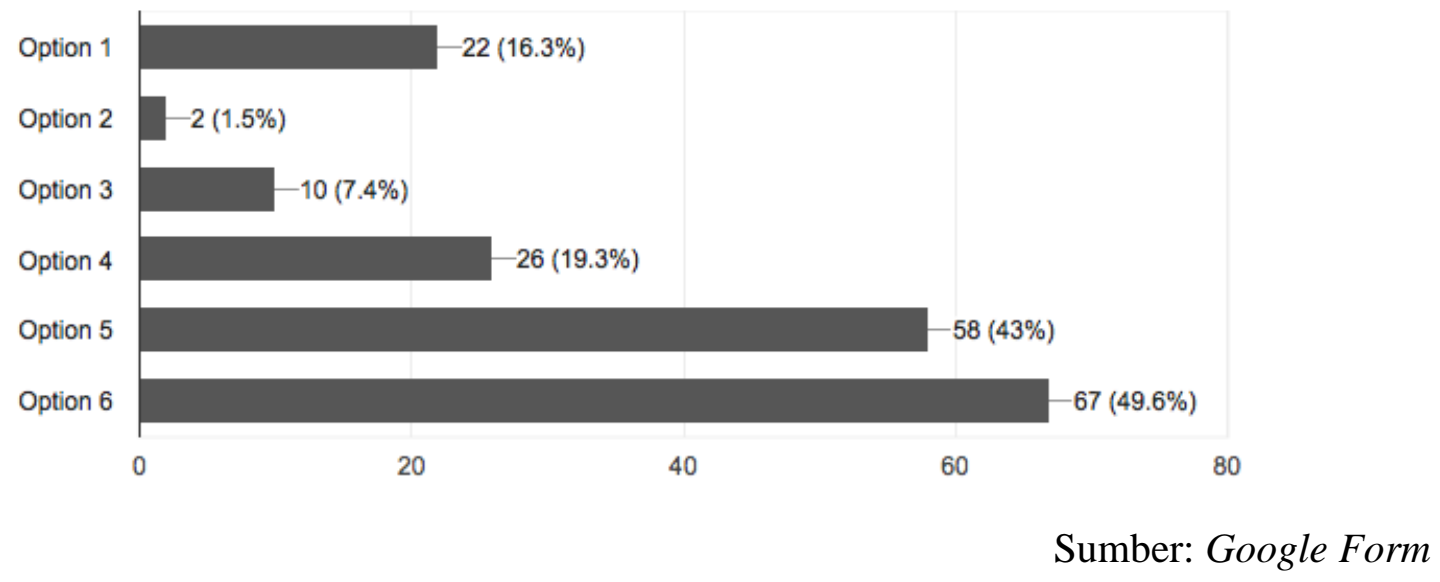

Gambar 5. Diagram Suasana Ruang

Dari hasil poling responses presentasi terbanyak yaitu option 5 dan 6 dengan suasana ruang yang feminim dan ceria 


\section{Hasil Wawancara dan Pembahasan}

Wawancara dilakukan dengan narasumber yaitu pengunjung Rumah Sakit Ibu dan Anak, wanita hamil, dan anak usia 5-10 tahun yang pernah menjalani perawatan di Rumah Sakit Ibu dan Anak. Wawancara terkait dengan bagaimana pengalaman mereka selama dirawat di rumah sakit dan kesan yang dirasakan ketika pertama kali berada dirumah sakit dengan pertanyaan yang diajukan berhubungan dengan interior rumah sakit.

Berdasarkan hasil wawancara dengan subjek SY sebagai anggota keluarga pengantar pasien menyatakan bahwa kesan pertama ketika berada di rumah sakit ibu dan anak yang pernah dikunjungi yaitu adanya rasa kurang nyaman karena suasana rumah sakit yang kaku, hal yang paling mempengaruhi perspektif SY terhadap rumah sakit dari segi visual interior yaitu warna. Kesan lain yang dirasakan ketika berada untuk waktu yang cukup lama di rumah sakit yaitu kurang nyaman dan bosan ketika menunggu perawatan pasien selesai.

Berdasarkan hasil wawancara dengan subjek IF yang pernah menjalani perawatan dari masa kehamilan hingga pasca melahirkan, menyatakan ketika melakukan perawatan seringkali merasakan rasa bosan ketika menunggu giliran perawatan hal ini disebabkan karena aktivitas yang dilakukan hanya duduk dan keterbatasan ruang gerak yang ada, apalagi ketika berada dalam situasi yang ramai di rumah sakit. Selain itu juga kurangnya elemen dekorasi pada interior rumah sakit yang menarik dan kurangnya suasana ruang yang dapat memberikan ketenangan dan kenyamanan. Ketika melakukan perawatan rasa takut yang dirasakan menjadi dua kali lipat apalagi ketika sudah memasuki trisemester 3, yaitu berupa perasaan takut untuk menghadapi persalinan, tegang, dan sensitif ketika memikirkan proses persalinan. Menurut IF, rasa takut tersebut juga dipengaruhi oleh suasana yang ada dirumah sakit yaitu suasana yang diciptakan oleh pengguna dan suasana yang diciptakan dari interior rumah sakit.

Berdasarkan hasil wawancara dengan subjek AI yang pernah menjalani perawatan masa pra kehamilan, pandangan pertama ketika masuk ke dalam rumah sakit dengan interior ruang yang cukup diperhatikan, AI merasa nyaman dan seperti tidak sedang berada di rumah sakit. Rumah sakit yang dikunjungi bernuansa warna pink dan cream sehingga ruang terkesan feminim Selain itu dari pencahayaan ruang yang menggunakan cahaya alami dan penggunaan warna hangat pada pencahayaan buatan yang memberikan rasa nyaman dan suasana ruang yang hangat.

Berdasarkan hasil wawancara dengan beberapa anak dengan rentang usia 5-10 tahun menyatakan bahwa ketika menerima keadaan masuk rumah sakit adanya rasa takut dan beberapa diantaranya bahkan menolak masuk rumah sakit dan secara terbuka meronta tidak mau dirawat. Reaksi yang timbul tergantung kepada kondisi kesehatan anak, sebagian besar mampu untuk mengerti alasan masuk rumah sakit. Kesan pertama ketika mereka masuk ke rumah sakit yaitu mereka merasa asing dengan suasana rumah sakit, rumah sakit memiliki kesan yang berbeda dengan tempat yang biasa mereka kunjungi. Anak-anak dengan rentang usia 5-10 tahun menyukai tempat dengan suasana yang menggambarkan karakter mereka dan menyediakan fasilitas bermain. Pada rentang usia 5-10 tahun rasa keingintahuan anak cukup tinggi, sehingga mereka akan merasa bosan jika hanya diam dan duduk ketika menunggu, akan lebih menyenangkan dan respon terhadap lingkungan yang lebih baik ketika mereka dapat mengeksplorasi lingkungan disekitarnya.

Dari hasil wawancara tersebut dapat diambil kesimpulan bahwa pengguna dan pengunjung rumah sakit ibu dan anak ketika pertama kali memasuki rumah sakit, aspek yang paling diperhatikan yaitu dari sisi visual berupa warna, pencahayaan, bentuk dan dekorasi yang dihadirkan oleh ruang yang akan memberikan pengaruh terhadap penilaian suasana pada ruang. 
Selain itu, suasana ruang juga dinilai dari bagaimana treatment interior yang diterapkan, hal tersebut dapat memberikan pengaruh terhadap rasa nyaman pengguna ketika berada untuk waktu yang cukup lama di rumah sakit.

\section{Kenapa dibutuhkannya penerapan tema pada interior?}

Berdasarkan fenomena dan isu yang terjadi pada kebanyakan rumah sakit, salah satu faktor yang dapat mempengaruhi persepsi manusia ketika berada di dalam sebuah ruang yaitu visual yang dihadirkan pada desain interiornya. Salah satu upaya untuk menciptakan ruangan yang dapat memberikan persepsi yang baik bagi penggunanya yaitu melalui penerapan tema interior, menentukan tema merupakan langkah awal dalam perancangan interior. Dengan penentuan tema interior akan menciptakan ruang yang terintegrasi dalam sebuah bangunan. Selain itu, melalui tema interior dapat merepresentasikan identitas dari sebuah lembaga, institusi, bahkan karakter pengguna pada ruang. Secara tidak langsung, penerapan tema akan memberikan ruang interior yang lebih menarik, memberikan karakter ruang yang sama pada masing-masing ruang, bahkan dapat menciptakan ruang yang bercerita.

\section{Penerapan Tema Pada Interior Rumah Sakit Ibu dan Anak}

Tidak terlepas dari fungsi rumah sakit ibu dan anak yaitu memberikan pelayanan dan perawatan kesehatan bagi wanita pada masa pra kehamilan hingga pasca melahirkan dan anakanak, maka dibutuhkan tema yang dapat menyesuaikan dengan fungsi dan kebutuhan pengguna ruang. Dengan pengguna utama yaitu wanita dan anak-anak, maka pemilihan tema yang sesuai yaitu melalui penerapan karakter pengguna yang direpresentasikan melalui ruang. Penerapan tema melalui karakter pengguna akan menjawab fenomena dan isu yang terjadi saat ini sesuai dengan hasil wawancara pada beberapa narasumber. Penerapan tema sesuai dengan karakter pengguna dapat menghadirkan suasana ruang yang diinginkan sehingga dapat membangun komunikasi yang baik antara ruang dan penggunanya. Tema ruang yang diwujudkan menjadi suatu desain yang berdasarkan pada karakter pengguna dapat menggunakan kata kunci yang mewakilkan karakter pengguna lalu diterapkan pada setiap elemen pembentuk ruang yaitu lantai, dinding, ceiling dan elemen pengisi ruang interior dengan memperhatikan aspek visual yang akan diciptakan, sehingga dapat ditangkap dengan baik oleh indera pengunjung.

\section{Tema Berdasarkan Karakter Pengguna}

Tema interior yang dapat membangun suasana yang diinginkan pengguna untuk diterapkan pada interior Rumah Sakit Ibu dan Anak berdasarkan hasil analisa yaitu suasana ruang yang sesuai dengan karakter pengguna terutama pasien yang merupakan pengguna yang memiliki peran penting di rumah sakit. Ibu dan anak memiliki beberapa karakter sebagai kata kunci yang dapat diimplementasikan melalui tema yang akan diterapkan pada desain interior rumah sakit. Dari hasil penelitian dengan metode kuantitatif diperoleh beberapa kata yang mencerminkan karakter seorang ibu yaitu penyayang, kuat, lembut, hangat dan ramah, dan karakter anak-anak yaitu lucu, ceria, dan memiliki keingintahuan yang tinggi. Tema pada elemen desain interior dapat diterapkan melalui bentuk ruang, pencahayaan, pemilihan warna, material, treatment dinding, lantai, ceiling, dekorasi dan penerapan desain pada signage area. Berikut beberapa tema yang dapat mengimplementasikan karakter pengguna dengan ruang.

\section{Tema yang menggambarkan karakter pengguna dengan menghadirkan suasana rumah (Hominess)}

Hominess adalah kualitas spasial yang membuat lingkungan yang dibangun terasa sebagai hunian (Hye Shin dan Maxwell, 2014). Rumah merupakan sebuah tempat tinggal dimana 
pengguna merasa nyaman dan akrab dengan suasana rumah. Berdasarkan kepada teori yang disampaikan oleh Schweitzer (2004) bahwa suasana suatu ruang yang memiliki efek pada penggunanya melalui peningkatan desain yang estetik dalam upaya untuk mengurangi tingkat stress dan kecemasan, meningkatkan kepuasan pasien, dan meningkatkan kesehatan dan penyembuhan. Suasana pada sebuah rumah biasanya akan mencermikan karakter dari penggunanya. Tema ini bermaksudkan untuk menyampaikan karakter ruang yang dapat memberikan suasana ruang seperti sedang berada dirumah meskipun pada kenyataannya pengguna berada di rumah sakit. Pada dasarnya, rumah merupakan cerminan dari karakter pemiliknya, begitu pun dengan tema yang akan diterapkan pada rumah sakit ini, yaitu menerapkan karakter pengguna nya. Melalui kata kunci yang menggambarkan karakter pengguna, yaitu :

- Ibu : Penyayang, kuat, lembut, hangat, ramah

- Anak-anak : aktif, ceria, dan keingintahuan yang tinggi

Melalui kata kunci tersebut, maka penerapan pada elemen interior akan mengimplementasikan karakter dari pengguna dengan merepresentasikannya melalui suasana seperti berada dirumah melalui penerapan material elemen pembentuk dan pengisi interior, bentuk ruang, furniture, dan layout, pemilihan elemen dekorasi, dan jenis pencahayaan yang diterapkan yang dapat mendukung terciptanya suasana yang sesuai dengan tema. Selain menghadirkan suasana seperti berada di rumah dari penerapan desain, penerapan tema pada interior rumah sakit juga dapat diterapkan dari jenis dan fungsi ruang di rumah sakit terutama pada ruang-ruang publik yang bersinggungan langsung dengan pengantar/keluarga pasien dan pasien yang di desain sesuai dengan karakter desain pada ruang-ruang yang terdapat dirumah. Dengan contoh sebagai berikut :

1. Ruang penerimaan (lobi) yang di desain seperti ruang tamu dirumah melalui penataan layout dan penggunaan fasilitas duduk berupa sofa dan coffe table. Selain itu, juga dapat diterapkan dengan pemilihan material berupa penerapan aksen kayu dan pemilihan jenis pencahayaan dan warna cahaya yang dapat memberikan kesan ruang yang hangat dan nyaman.
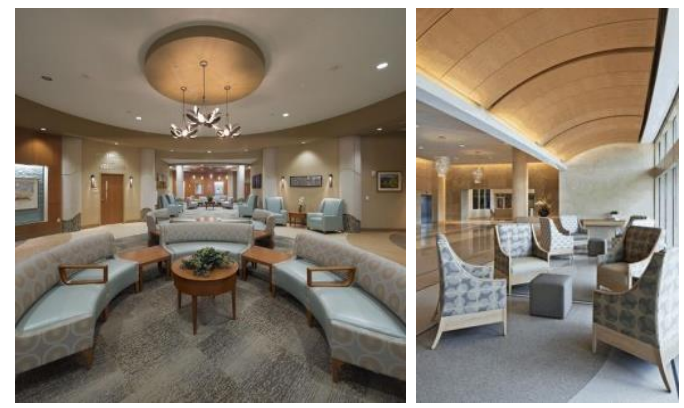

Gambar 6. Studi Image 1

Sumber: Google Form

2. Ruang rawat inap yang di desain dengan suasana seperti kamar tidur dirumah melalui pemilihan headwall, furniture, dekorasi, warna, pencahayaan dan material yang dapat menggambarkan suasana kamar tidur dirumah. 

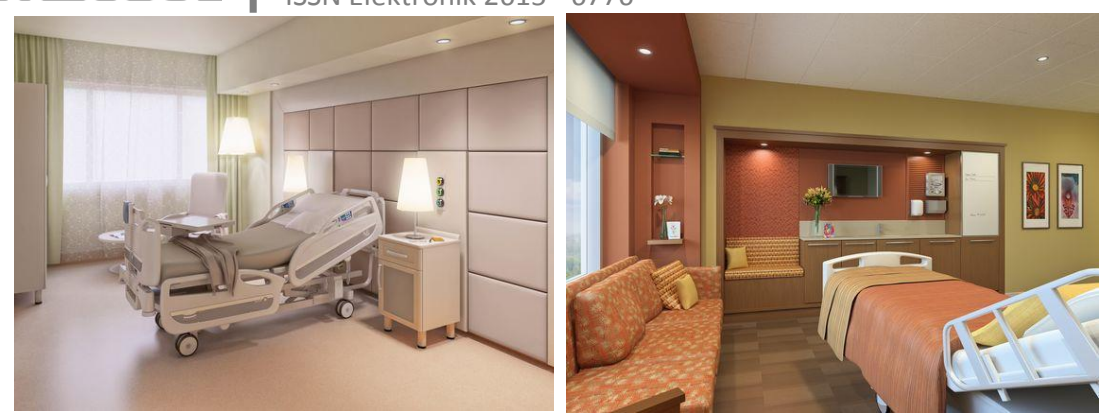

Gambar 7. Studi Image 2

Sumber: Pinterest

3. Ruang pemeriksaan (poliklinik) yang di desain seperti ruang kerja dapat diterapkan dengan memperhatikan bentuk furniture dan memperhatikan pemilihan treatment interior yang digunakan.

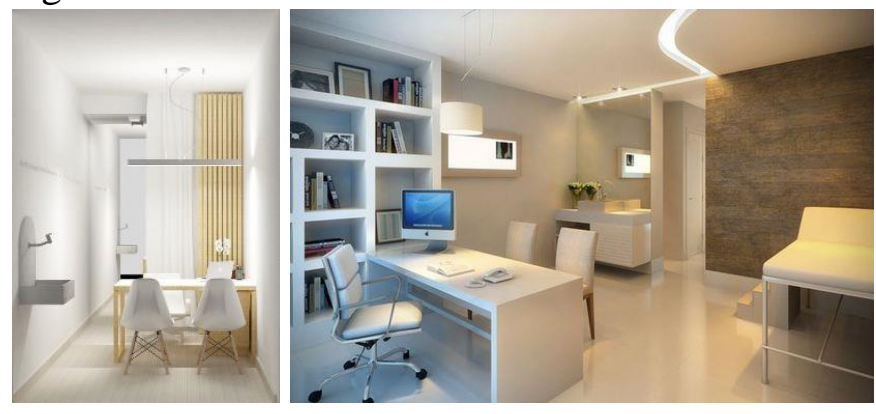

Gambar 8. Studi Image 3

Sumber: Pinterest

Selain dapat menciptkan suasana ruang yang dapat mencerminkan karakter penggunanya, dengan penerapan tema hominess yang menghadirkan suasana rumah juga dapat menciptkan kesan ruang yang hangat, nyaman, dan ramah.

\section{Tema dengan penerapan elemen pembentuk dan pengisi ruang yang mengekspresikan karakter ibu dan anak}

Tema ruang yang akan diwujudkan menjadi suatu desain yang berdasar pada karakter pengguna dapat dikaji ke setiap unsur desain sehingga dapat ditangkap dengan baik oleh indera pengunjung melalui analisis persepsi mereka dan akan menciptakan komunikasi yang baik antara ruang dan pengunjung di dalamnya (Sjach, 2012). Berdasarkan kepada teori tersebut, penerapan tema yang dapat mengekspresikan karakter ibu dan anak akan dikaji melalui penerapan pada elemen pembentuk dan pengisi interior. Pertama, elemen desain yang mengekspresikan karakter "kuat" seorang ibu melalui penerapan bentuk yang geometris. Menurut teori yang disampaikan oleh Kandinsky (1979) menyatakan bahwa bentuk cenderung mendominasi persepsi manusia karena dengan bentuk dapat lebih memahami rasa ruang, bentuk geometris dalam desain memiliki rasa yang spesifik seperti kebaikan dan kekuatan untuk menyenangkan. 


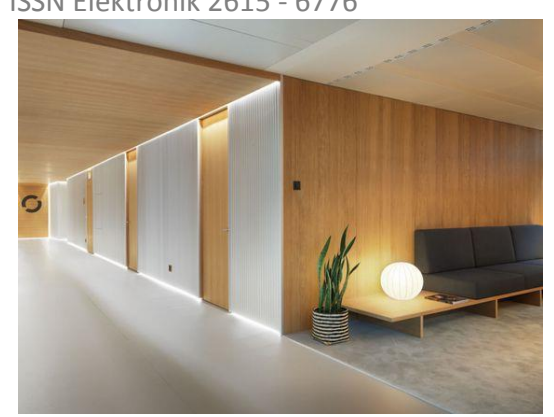

Gambar 9. Studi Image 4

Sumber: Pinterest

Kedua, karakter "hangat dan ramah" dapat diterapkan dengan penggunaan material seperti material kayu yang memberikan kesan ruang yang hangat dan ramah melalui pemilihan tekstur dan warna kayu. Untuk mengekspresikan karakter hangat juga dapat dilakukan melalui pemilihan warna pencahayaaan yang dapat memberikan kesan ruang yang hangat.

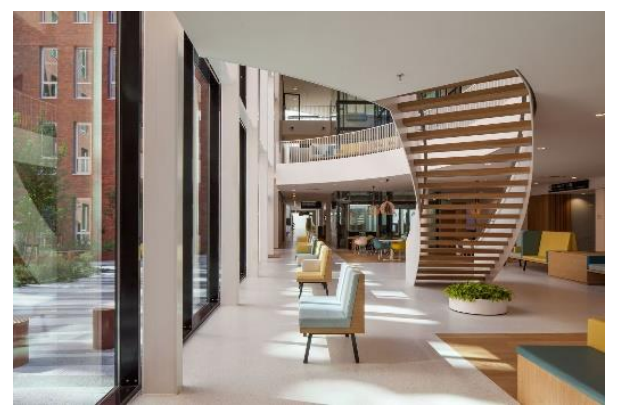

Gambar 10. Studi Image 5

Sumber: Pinterest

Ketiga, karakter "penyayang" dapat diekspresikan pada ruang melalui pemilihan bentuk furniture dengan penerapan bentuk dasar lingkaran, dimana bentuk lingkaran atau lengkung memiliki kesan melindungi dan dari sisi psikologi bentuk yang muncul yaitu kasih sayang. Ruang yang mengekspresikan karakter "lembut" dapat diterapkan melalui pemilihan warna dan tekstur. Biasanya warna yang dapat mencerminkan karakter wanita identik dengan penggunaan warna dengan tone warna yang lembut seperti pink, hijau tosca, ungu yang juga memberikan kesan ruang yang feminim.
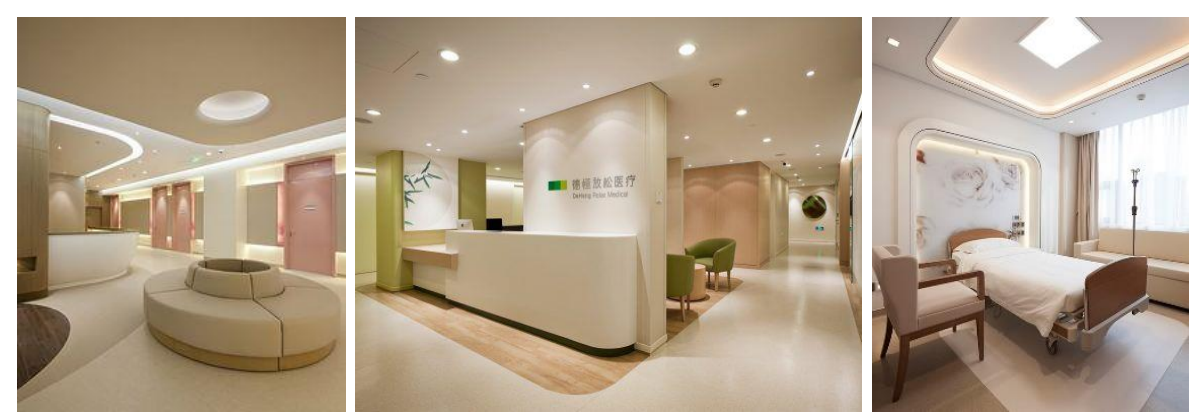

Gambar 11. Studi Image 5

Sumber: Pinterest

Keempat anak-anak, anak-anak memiliki sifat yang ceria, pada ruang interior yang mengekspresikan karakter ceria anak dapat diaplikasikan melalui pemilihan warna-warna ceria 
yang disukai oleh anak-anak. Menurut Lambert (2013), anak-anak lebih menghargai lingkungan interior yang mencerminkan kebutuhan dan minat yang berkembang sesuai dengan kebutuhan fasilitas/aktivitas bermain yang sesuai usia di area tunggu, interior yang kreatif dan nyaman dalam penerapan warna, bentuk, pola, dan teksture. Untuk menyikapi teori tersebut dan menyesuaikan dengan karakter anak yaitu memiliki keingintahuan yang tinggi, maka dibutuhkan ruang interior yang dapat memberikan interaksi dan memberikan daya tarik bagi anak. Ruang yang interaktif dapat diterapkan melalui media visual dan media bermain yang menarik bagi anak-anak seperti penerapan Interactive touch screenwall. Berikut contoh penerapan pada ruang yang mengekspresikan karakter anak-anak.

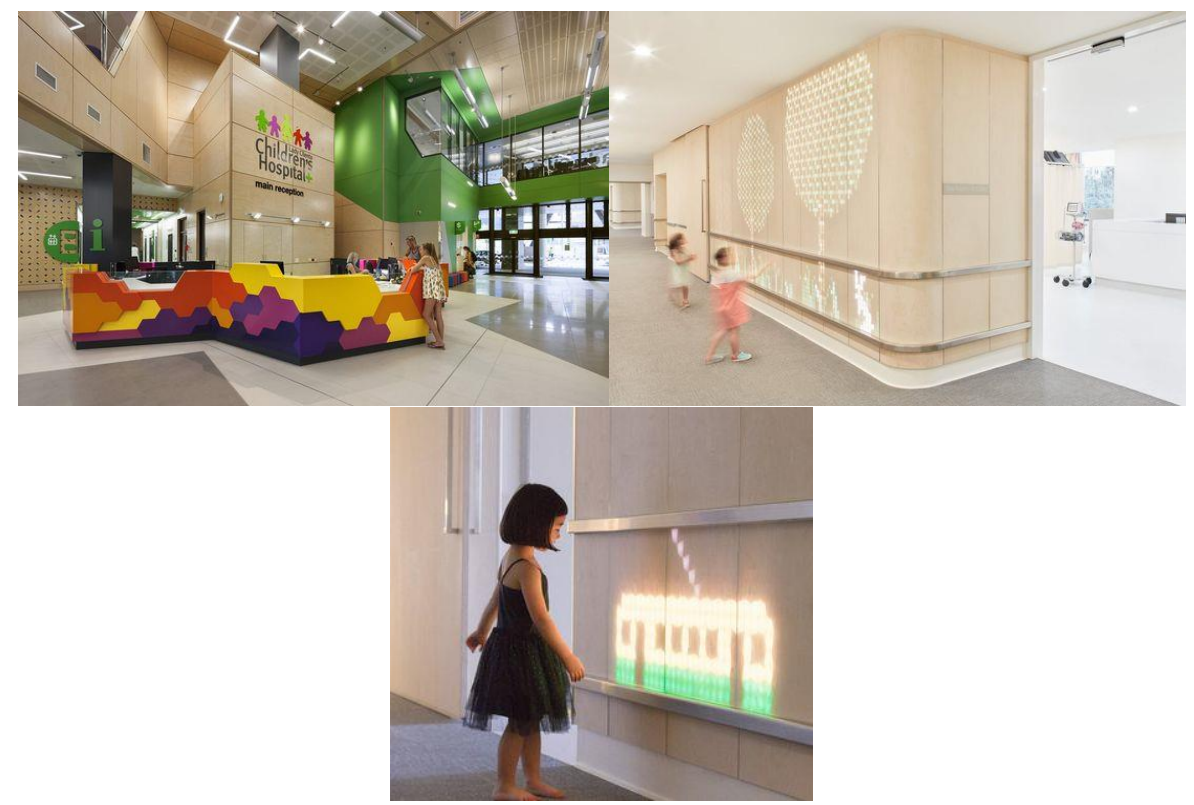

Gambar 12. Studi Image 6

Sumber : Pinterest

Dengan menciptakan desain interior yang menggambarkan karakter pengguna dapat memberikan ruang yang nyaman dan tidak terasa asing bagi pasien sehingga dapat memberikan persepsi ruang yang positif.

\section{KESIMPULAN}

Tema pada interior ruang selain dapat membangun atmosphere yang dapat mempengaruhi persepsi dan penilaian pengguna terhadap ruang, tema juga bertujuan untuk dapat menciptakan keseragaman pada desain yang di aplikasikan, sehingga dapat membentuk sebuah image/pandangan pada sebuah rumah sakit. Metodologi desain dengan menerapkan karakter ibu dan anak melalui tema ruang dengan penerapan pada elemen-elemen desain interior yang terlihat secara visual seperti treatment ceiling, dinding, dan lantai merupakan salah satu metode yang diterapkan berdasar kepada hasil survey yang disetujui oleh para responses, wawancara dengan beberapa narasumber yang pernah mengunjungi dan menjalani perawatan di Rumah Sakit Ibu dan Anak, dan beberapa teori-teori pendukung. Berdasarkan hasil penelitian ini, penerapan karakter pengguna pada interior rumah sakit dapat diwujudkan melalui penerapan bentuk, warna, pencahayaan, material, furniture, dan unsur dekoratif pada ruang. Sehingga dapat disarankan bagi para desainer interior dan rumah sakit untuk dapat menerapkan metode serupa, tetapi tidak menutup kemungkinan untuk pengaplikasian dan pengkajian tema yang sesuai untuk rumah sakit ibu dan anak melalui metode lainnya. 


\section{DAFTAR PUSTAKA}

[1] Lawson, B. dan Phiri, M. (2000) Room for Improvement. Health Service Journal 20 January 2000. Pp 24-27. Diakses melalui www.reasearchgate.net

[2] Rahardjo, Setiamurti dan Handoyo, Andreas. (2015), Analisa Konsep Tematik dan Taman Perumahan di Kota Baru Parahyangan Sebagai Daya Tarik Bagi Anak-Anak, Jurnal Tesa Arsitektur, Vol. 13 No. 2, ISSN 1410-6094.

[3] Whaley, W. (2018) Coenesthesia: An Aesthetic of Healing through Hybrid Reality Art.

[4] Annemansetal. (2017) Informing Hospital Design through research on patients experience.

[5] Ozkan, Aysen. (2017) Influence of Design Styles on User Preferences in Hotel Guestroom.

[6] Wahyudie, Prasetyo. Redesain Interior Rumah Sakit Negri Kelas B dengan Konsep Healing Environtment, Available at http://ejurnal.its.ac.id/index.php/sains_seni/article/view/20400 Accessed : 2018-04-09

[7] Kusnaedi, Iyus., Desrio, Misael., Agustanu, Faisal Rahman. Tinjauan Komponen dan Elemen Interior Pada Restoran (Studi Kasus Dinding Masif Solaria PVJ dan BEC Bandung, Available at https://ejurnal.itenas.ac.id/index.php/rekajiva/article/view/182/0 Accessed: 2018-04-26

[8] Sjach, Sheila., Handajani, Rinawati P., Amiuza, Chairil B. Penerapan Unsur Warna pada Interior Museum dengan Objek Sejarah Perkembangan Islam di Jawa, Available at http://arsitektur.ub.ac.id/en/penerapan-unsur-warna-pada-interior-museum-denganobjek-sejarah-perkembangan-islam-di-jawal Accessed: 2018-04-22

[9] Vanja Bogicevic, Milos Bujisic, Chihan Cobanoglu, Andrew Hale Feinstein. (2018) Gender and Age Preferences of Hotel Room Design. International Journal of Contemporary.

[10] Hospitality Management, Vol. 30 Issue: 2, pp.874-899, Available at http://doi.org/10.1108/IJCHM-08-2016-0450

[11] Mc Cullough, Cynthia (2009) Evidence-Based Design For Healthcare Facilities, Canada.

[12] Lambert, Coad, Hick, Glacken. (2013) Young children's perspectives of ideal physical design features for hospital-built environment, Available at https://scihub.tw/10.1177/1367493512473852 Accessed: 2018-05-24

[13] Schweirzer, Gilian, Frampton (2004) Healing Spaces: Elements of Environmental Design That Make an Impact on Health, Available at https://scihub.tw/10.1089/acm.2004.10.S-71 Accessed: 2018-05-24 